\title{
Tweeting dignity: A practical theological reflection on Twitter's normative function
}

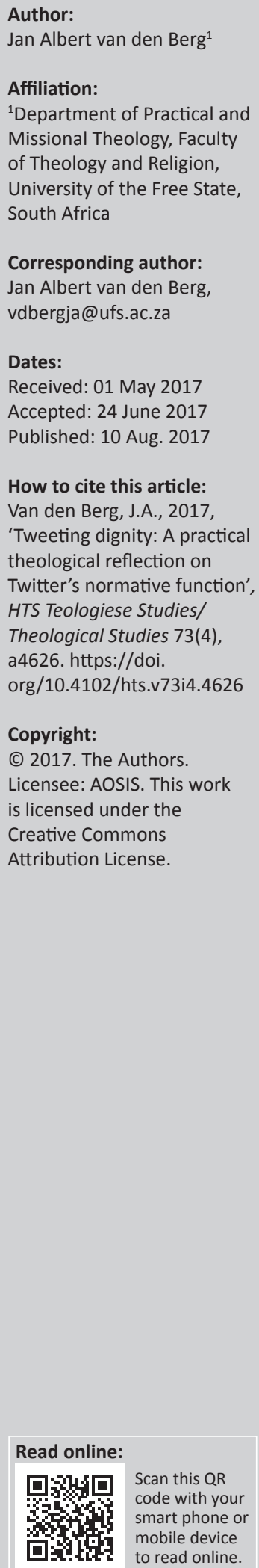

Social media makes an important contribution to a rapidly changing world in which various domains of meaning are described anew. The evolving nature and dynamic character of social media therefore provides for a rich praxis terrain with which to interact from a practical theological orientation. More specifically associated with the theme of this contribution, the social media sphere also provides an excellent space not only to rethink but also to reenact expressions of dignity in society. The research is facilitated from a practical theological orientation, with particular focus on a normative dimension as embodied in aspects of dignity. Through the use of an interdisciplinary approach and methodology, some contours of dignity specifically associated with South African politics as well as the so-called Charlie Hebdo attacks in 2015 in Paris expressed on the social media platform, Twitter, are described and discussed. From this empirical analysis, description and discussion, a practical theological reflection is offered in which aspects of dignity associated with a normativity function are described. Some practical theological perspectives contributing to future relevant tweeting on dignity are also formulated and provided in conclusion.

\section{Introduction}

In presenting a contribution to the Festschrift of colleague Yolanda Dreyer, I acknowledge her as a colleague and friend whose life and message carry an exceptional influence. Not only as one of the first female ministers in South Africa, but also as a rated and recognised international academic, she makes a unique contribution to the expansion of practical theology. The uniqueness of Yolanda's contribution is underlined by the fact that, as a scholar with doctorate degrees in Practical Theology and New Testament, she personifies the establishment of a multidisciplinary scientific methodology that gives scope to persons marginalised in various ways. This has led to Yolanda's research having a strong relevance-contextual character with topical themes related to the embodiment of dignity being emphasised.

In the light of and in line with Yolanda's sensitivity towards topical research themes, I note in my contribution the influence and meaning of social media on the formulation of theological content in which a dynamic interpretation of dignity functions strongly. In the acknowledgement of the meaning of context, I note especially the growing meaning and importance of social media, and in particular the micro-blogging platform, Twitter. The research is guided by a practical theological enquiry as to how the theme of dignity is formulated in a dynamic way on Twitter, leading to the construction of a new relevant understanding of normativity.

In the outline of the research, an attempt will be made to demonstrate the classical spiral movement of practical theology between practice and theory, as motivated by Browning (1991:41). The overall outline of the article will thus consist of two broader movements, namely (1) a movement from practice to theory, and (2) a movement from theory to practice. I will firstly start by presenting a practical theological description of a Twitter polemic between two prominent South Africans, showcasing aspects of a contextual understanding of dignity. By referring to the Steve Hofmeyer and Conrad Koch/Chester Missing incident a local and contextual case study will be offered (News24 2015:n.p.). This is followed secondly by a short introduction in which social media, and in particular Twitter as an important platform, is described as a prominent driver of a changing world. Thirdly, these theoretical perspectives are followed by empirical research in which the so-called Charlie Hebdo attacks in 2015 in Paris (BBC 2015:n.p.) are presented, analysed and discussed. In the last section of the article a critical practical theological reflection is offered, with specific strategic perspectives, as interpretation and elucidation of the normativity associated with Twitter messages on dignity. 


\section{Tweeting dignity?}

\section{A South African Twitter polemic - A case in time}

The polemic on Twitter in South Africa between the singer, Steve Hofmeyer, and Konrad Koch through his puppet and alias, 'Chester Missing', has been reported widely in the South African media. The following report from eNCA (2014a) conveys the background to this well-commented event:

JOHANNESBURG - It's off to court for a bout in the ring between Steve Hofmeyr and Chester Missing. Comedian and ventriloquist Conrad Koch - the personality behind the puppet - will be opposing the Afrikaans singer's interim protection order against him, in the Randburg Magistrates Court on Thursday. Hofmeyr secured the order on November 5, in which it stated that the respondent was, among others, barred from harassing or threatening the applicant or making defamatory remarks against him. Koch, tweeting under the user-name of his puppet @ chestermissing, immediately defied the gag order with this response via Twitter: 'Haha. Stevo, I am gonna burn $\mathrm{u}$ for this one'. Hofmeyr and Koch/Missing have repeatedly come to blows. In October last year, a lively Twitter exchange between them led to Hofmeyr blocking tweets by @chestermissing. The latest fracas reportedly stemmed from an opinion piece by Koch in The Times, in the role of political commentator. Koch placed Pick n Pay and Land Rover under scrutiny by questioning their sponsorship of the Afrikaans is Groot (AIG) music concerts in Pretoria, at which Hofmeyr performed this month. This was in response to Hofmeyr's earlier tweet about apartheid in October, 'Sorry to offend but in my books Blacks were the architects of Apartheid. Go figure.' The tweet caused a stir on social media and Hofmeyr was accused of being racist, stupid, and a peddler of ignorance. One company, Williams Hunt in Port Elizabeth, then withdrew a sponsored bakkie which was meant to be used by Hofmeyr during his PE gigs. The ANC Youth League (ANCYL) reacted to the tweet by saying while they fully respected the right of all national groups to practice their cultures in peace, they wholeheartedly condemned the statements made by Hofmeyr. As such, they had planned to march against Hofmeyr at Moreleta Church between November 14 and 22, when the AIG festival was taking place, but their application to protest was declined by the Tshwane municipality. Hofmeyr remains active on social media and has put out a request asking to be informed if Koch mentions him or his sponsors, saying this would form the basis of an additional subpoena against the puppeteer. He has also stated that until Koch explained the 'hate speech' in court on November 27 , the ventriloquist was not allowed to contact him, his sponsors or his business partners directly or indirectly. Koch, meanwhile, has said his tweets against Hofmeyr could not amount to hate speech, as he'd never said anything hateful about the singer, according to a report by Beeld newspaper. (n.p.)

From this report it is clear that the interplay of various multifaceted perspectives as reflected on social media, and in particular in this case, on the Twitter platform, provides for an important praxis terrain for practical theological reflections regarding dignity.

\section{Perspectives of the Steve Hofmeyer and Conrad Koch/Chester Missing incident}

The two main characters in the above described debate are Steve Hofmeyer and Conrad Koch who participates through his hand puppet, Chester Missing. Hofmeyer is a well-known Afrikaans actor and a prominent singer. He is also a writer and politically active, in particular with aspects associated with Afrikaans and the promotion of its culture (Hofmeyr 2015:n.p.). Koch grew up in a primarily English environment and obtained a degree in social anthropology at the University of Cape Town. He became well known through the use of Chester Missing, who delivers satirical political comment (Koch 2015:n.p).

The core of the debate concerns provocative political remarks, in particular by Hofmeyer on Twitter, which resulted in challenging tweets by Koch/Chester Missing. This resulted in wide media coverage and a court challenge by Hofmeyer requesting a restraining order against Koch/Chester Missing. This was denied with cost on 27 November 2014 in the Randburg Magistrate's Court, with Magistrate Budlender significantly commenting that:

... a society that takes itself seriously risks bottling up its tensions and treating every example of irreverence as a threat to its existence. Humor is one of the solvents of democracy. (eNCA 2014b:n.p.)

The underlying layers of this incident pose the question to practical theology if social media, and more specifically Twitter, provide an easily accessible space with a large audience, for example, a new formulation and presentation of normative aspects of dignity ${ }^{1}$ This research endeavour aligns well with Osmer's (2008:n.p.) third task of practical theological inquiry, namely the normative, in which the focus is placed on the construction of theological and ethical norms as well as providing some examples of the so-called best practices (Osmer \& Schweitzer 2003:3). In the following subsection a brief overview of social media, especially Twitter, and aligning with newer developments in practical theological, will be provided.

\section{Practical theology and Twitter?}

In this section of the article the development in practical theology, on the one hand, is described as orientation point for the research. On the other hand, a motivation is presented as to why Twitter presents an important space for practical theological involvement and research.

\section{Theology in practice}

Practical theology has a rich history of development. Initially, practical theology was seen as a so-called application science in which future ministers are prepared for church practice. The focus for practical training was primarily on activities taking place within the church walls. Practical training was then also strongly characterised by a deductive methodology with the acknowledgement of normative sources such as Scripture and tradition, to which high authoritative value

1. When we translate a theological concept of human dignity into concrete rights language, we might state that human dignity implies respect for the equal autonomy language, we might stathe of each person and the right not to bedevalued or treated in manner. Human dignity does not reside within the individual, but expresses a normative status that is imparted to every human being, regardless of origin, capability, success, gender or race (Vorster 2012:5/6). 
was awarded. Through this understanding the normative perspectives developed by way of other theological disciplines, such as biblical and dogmatic sciences, are applied in practice through the facilitation of practical theology. In this regard Ganzevoort (2014) wrote the following:

In the history of our discipline, there has been a strong current of understanding practical theology as applied theology. That is, practical theology was understood as the discipline where theology was applied to practice, especially to the professional practice of ministers and priests. Practical theology added the layout and presentation so to speak to the texts that other theologians had written. (p. 20)

The practical application of these normative principles was mainly focused on the congregational context. The facilitation of the fixed normative principles has the character of a linear model of communication within which specific truths are conveyed.

Because of the development in the practical theological science and directly influenced by factors linked to postmodernity, more and more attention was given from the end of the previous century to the description and interpretation of activities outside of the church walls as part of everyday life. Being strongly practice orientated (Hermans 2014:1210), '[a]ttending to the empirical is an important element of contemporary practical theology' (Osmer 2014:61). The defined meaning of context has become increasingly important. In the discussion regarding context the dynamic interpretation of the Scriptures and tradition is emphasised. As a result normativity was described in terms of a strong contextual connectedness. ${ }^{2}$

This development is further supported through a movement which does not only focus on clergy functions (clerical paradigm) and church functions (ecclesiocentric models of practical theology). A growing awareness has developed with the acknowledgement of primary non-church-orientated practices in which 'religious praxis within the context of public life in its various dimensions is recognized' (Osmer \& Schweitzer 2003:5). The awakening in the study of spirituality, the development of the so-called 'ordinary theology'3 and 'lived religion' has contributed towards the empirical exploration of the world outside the doors of the church. ${ }^{4}$ The focus of an empirical practical theological description should therefore not only encompass church practices, but also, in

2.Practical theologians know and take responsibility for the fact that each phase of our work operates by explicit and implicit theological commitments ... Practical our work operates by explicit and implicit theological commitments ... Practical
theologians reflect on the contours of lived human experience in relation to a wide range of theological issues including the transcendence and immanence of God, the problem of evil and human suffering, human knowing, means of change and transformation, and the relationship between divine and human action... Some even make the bold case that new theological insight can come about through empirically based investigations of human experience in particular contexts (Cahalan \& Mikoski 2014:5).

3. For the church's openness to ordinary life should entail and openness to ordinary theology, and an acceptance of ordinary theology's openness to change, both with respect to the theology of churchgoers and of those beyond the church's more conspicuous portals. Ordinary theology is truly a warts and all theology, open to the alley (Astley 2002:161).

4.The well-known sociologist Nancy Ammerman echoed this in the following words: 'Finding religion in everyday life means looking wherever and however we find people invoking a sacred presence' (Ammerman 2014:191). particular, daily life. In this regard Ganzevoort and Roeland (2014) write:

The concepts of praxis and lived religion focus on what people do rather than on 'official' religion, its sacred sources, its institutes, and its doctrines. As such, practical theology has much in common with what in disciplines like anthropology, sociology, and media studies, is known as 'the practical turn': the turn away from institutes and (cultural) texts to the everyday social and cultural practices of ordinary people. (p. 93)

The character of activities taking place on the street, as well as development in scientific methodology, thus presented possibilities for an inductive approach that in turn presents unique challenges to the interpretation of normativity. From an inductive methodology the locus of practical theology shifted to the recognition of the theological load and normativity inherently linked to practices. Currently the developing concept of 'lived religion' is commonly used as an expression of this development in practical theology.

\section{Twitter theology?}

The origin, growth and use of mobile cellular phone technology and the Internet over a period of more than two decades have changed the world forever. One of the direct results of the use of the Internet was the origin of the social media revolution. Driven by the initial establishment of the Facebook platform, various other forms of social media, for example Twitter and Instagram, have seen the light over the past decade. In view of the previous description on the development of practical theology, it is thus obvious that the scope of social media suggests an important context for further reflection. Fuchs (2014) has therefore rightly indicated that:

Social media is a complex term with multi-layered meanings ... Understanding social media critically means, among other things, to engage with the different forms of sociality on the Internet in the context of society ... (pp. 6-11)

For the purpose of the research I focus on the use of the Twitter platform. The use of shorter text messages with usually a limit of 140 characters offers empirically favourable data, especially in the light of the research aim, namely the formulation of popular theological content and to determine the normative value given to it (Holmberg, Bastubacka \& Thelwall 2016:340). In order to further focus the empirical question, the prevalence of dynamic expressions of dignity on Twitter is noted.

\section{Expressions of dignity on Twitter? Empirical overview of Twitter data on the Charlie Hebdo attacks}

The Charlie Hebdo attacks during January 2015 in Paris (BBC 2015:n.p.) have been selected as an initial practice terrain investigation for two reasons. Firstly, it presents a good and relevant indication of the general use of Twitter as part of social media comment and, secondly, it indicates how the theme of dignity is associated with a specific 
multilayered incident on social media. In the presentation of these practice examples, a contribution is made towards a reflection regarding the praxis of dignity within a social media environment. ${ }^{5}$ The description is further enriched by the presentation of preliminary and relevant theoretical perspectives.

With regard to this specific research the orientation of observation was carried out by a social media consultation company, Fuseware (2015) - which has access to the daily Twitter stream of all tweets. ${ }^{6}$ With the assistance of this company a refined search was carried out about the incidence of references to certain events by using sophisticated software. Because of the high incidence of data the search for tweets had to be refined, and certain keywords with a strong Christian-orientated subtheme were identified. The following were some of the most important findings:

- All keywords relating to the Charlie Hebdo attacks and associated hashtags (namely, \#charliehebdo and \#jesuischarlie) in the context of the identified Christianrelated keywords were searched for. This, therefore, represents a Christian-biased subset of the Charlie Hebdo conversations.

- In terms of volume, almost all of the conversation happened in early January 2015 after the attacks had taken place. By February 2015, the conversation had sharply declined to a small fraction of the initial spike, indicating how quickly a conversation around topics gets stale on social media.

- The automated sentiment was identified to be mainly negative, as expected, with $48 \%$ of the content having negative connotations, while $50 \%$ of the content remained neutral. The content originated from a $66 \%$ male audience, mainly an older $(35+)$ demographic. Most of this content originated from the USA and Europe, with a small fraction coming from Africa.

- Aside from the main hashtags around the event, the top words used were faith', 'God', 'Christian', 'Pope' and 'Jesus'. In terms of authoritative content from influencers, the top post from the Washington Post shared an article on the Pope's remarks on Charlie Hebdo: 'You cannot insult the faith of others'. This resulted in widespread criticism, as it seemed to go against the fundamental tenets of free speech. Other authoritative posters included Associated Press, Huffington Post, Time.com and the Wall Street Journal - mostly all postings about the Pope's remarks on the subject.

Looking at some of the most popular individual tweets in terms of a normative accent the following can be noted:

5.Social media are not the causes of revolutions and violence, they are rather a mirro of the power structures and structures of exploitation and oppression that we find in contemporary society' (Fuchs 2014:204).

6.Without an over-elaboration of technical details, the Twitter stream Application Programming Interface (API) allows access to 'streams' of public data flowing through Twitter. This is done by accessing what Twitter calls 'the Public through Twitter. This is done by accessing what Twitter calls the Public Firehose'... Twitter limited public access to the Firehouse stream to the first per cent of the available Tweets at any given mossible to view and analyze one per cent of the public generated Tweets every 'streaming second' into a database. This is commonly called 'Twitterdata mining' (Lutz \& Du Toit 2015:n.p.).
The most retweeted post was not related directly to the attacks, but put things into perspective with another previous situation in Norway (see Figure 1).

Some other popular and important shared tweets with a strong explicit emphasis on the normative character of dignity include the following (see Figure 2 and Figure 3).

\section{Tweeting dignity - Twitter's normative function?}

Normativity is a multicoloured concept, which is found across a wide range of disciplines and in various contexts. A good example of this is to be found in the contribution of Stoehr (2016:n.p.) regarding the normativity associated with writing and spelling in social media practices. The focus in this research is however on normativity in theological discourse which is generally associated with 'divine action' (Root 2014:12). Henriksen (2006) describes the relation between theology and normativity as follows:

$[N]$ ormativity of theology is related to how it, by and through its enterprise, makes it possible to reconstruct and accessible

ChristianChristensen @ChrChristensen

L+ Follow

Breivik killed 77 in Norway \& no-one asked me as a white male of Nordic Christian background if I felt the need to condemn it. \#CharlieHebdo

Source: @chrchristensen, 2015, ‘Prof. of Journalism at Stockholm University. American. Also Source: @chrchristensen, 2015, 'Prof. of Journalism at Stockholm University. American. Also
lived in UK \& Turkey. @Guardian \& @CommonDreams contributor. Tweets own opinion, not lived in UK \& Turkey. @Guardian \& @ CommonDreams contributor. Tweets own opinion, not
my employer's', viewed 23 September 2015, from https://twitter.com/ChrChristensen/ my employer's', viewed 23 sep
status/552903106556870657

FIGURE 1: Most retweeted post regarding the Charlie Hebdo attacks.

\section{7) Glen Gilmore \\ D. @GlenGilmore}

2. Follow

RIP \#AhmedMerabet, a Muslim police officer murdered trying to save \#CharlieHebdo, who mocked his faith. \#JeSuisAhmed

Source: @glengilmore, 2015, 'FORBES top 20 social media http://bit.ly/10405Mx TIME Man of Action http://goo.gl/KISPW Speaker \#DigitalMarketing Author \#DigitalTransformation \#AI \#AR \#lOT Rutgers Adj', viewed 24 September 2015, from https://twitter.com/ GlenGilmore/status/553555389611274240

FIGURE 2: Important perspective on religious tolerance.

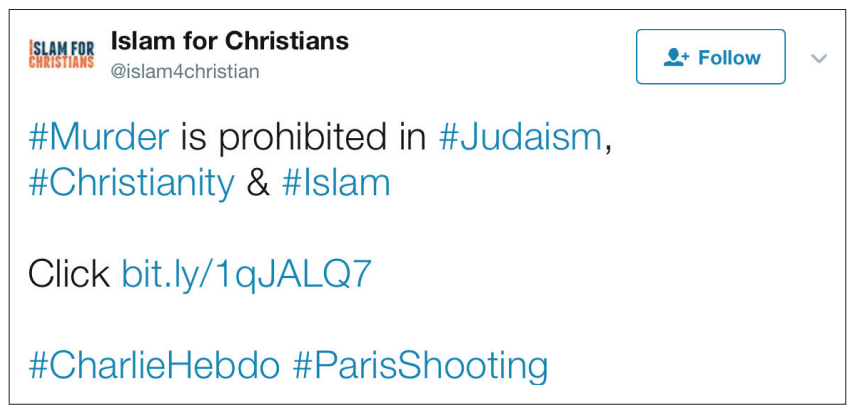

Source: @islam4christians, 2015, 'This account intends to be a main informative online source of knowledge about the true message of Prophet Jesus and how Muslims view him' viewed 24 September 2015, from https://twitter.com/islam4christian/ status/55313951517155737

FIGURE 3: Religious condemnation of murder. 
the reasons for what counts as the normative doctrines of the church as well as to suggest proposal for articulations of such normative doctrines. (p. 215)

In negotiating proposals for the articulation of normative doctrines, a strong emphasis is usually placed on the socalled four traditional sources of Christian theology, namely Scripture, tradition, reason and experience (Osmer 2012:338). These sources are used to negotiate a specific normative position within theological discourse. Cameron et al. (2010:53-56) described this process of negotiation by way of a 'theology in four voices'. According to this model, the four voices of theology, constantly interacting with each other and singing in the choir of theology, consist of the following:

The first voice is that of normative theology strongly associated with Scriptures, the creeds, official church teaching and liturgies. Formal theology is responsible for the second voice and consists of the theology of theologians as well as the dialogue with other disciplines. The third voice is that of the so-called espoused theology, which is embedded within the articulations, used by a group to express its beliefs. Lastly operant theology is expressed within the actual practices of the group.

The growing articulation of especially the last two mentioned voices, namely that of espoused theology and operant theology, reflects the development of normativity in the Christian theology and, in particular, practical theology. This contextual-sensitive orientation has caused the seizure of a one-sided proclamation model in which the so-called truths are proclaimed in an a-contextual way. Instead a postmodern practical theological orientation would see the Christian tradition as 'fundamentally open' and to be constructed by a contextual sensitive 'faith from below' (Beaudoin 2014:196). Some postmodern practical theologians would therefore indicate that the formulation of a contextual-driven normativity is at most of preliminary nature and in constant flux (Wigg-Stevenson 2015:3). ${ }^{7}$ However, in articulating these aspects of normativity, the emphasis lies more on the creation of a discussion rather than on proclaiming certain unconditional truths. In this regard Wigg-Stevenson (2015) has boldly stated the following:

$[T]$ heology can no longer imagine itself as able to boldly proclaim truth from outside the exuberant chaos of daily life. Rather, theology must take the risk of stepping inside the action-or rather, the risk of acknowledging that is where we have always been-to humbly extend the hand of friendship to those we meet therein. It must seek to work with faithful partners beyond those voices codified in authoritative texts, and whose lives still bear the presence of God. Theological normativity in such a model shifts the goal away from proclamation, which requires hearers of the word, towards conversation. (p. 8)

7.Nevertheless, the messy process of identifying, understanding, and negotiatin these normative dimensions remains a conundrum. Acknowledging this messiness and complexity, I suggest, is not a way of escaping the conundrum, but a way of dealing with it in a constructive and responsible way (Kaufman 2016:160).
This orientation has however led to the critique that although practical theology has developed into a discipline that has become fluent in talking about concrete human practice, it has become hesitant in speaking about God's action from the locale of the concrete (Root 2014:13). Taking these perspectives as well as the critique seriously and in discerning the normative task of practical theology, Osmer and Schweitzer (2003) provide the following important reference:

The normative task of practical theology focuses on the construction of theological and ethical norms by which to critically assess, guide, and reform some dimension of contemporary religious praxis. It asks the question: What forms ought religious praxis take in this particular social context? Here, practical theology looks in two directions simultaneously. It looks to the resources mediating truth, goodness, and beauty in a particular religious tradition and to the problems and possibilities of contemporary religious praxis in the particular context under investigation. While it is primarily at this point that practical theology will enter into dialogue with other theological and ethical disciplines, the norms of praxis it develops are not merely the application of the normative proposal of these fields. This is because the norms it develops take into account the particularities of the context of praxis it is seeking to address. Norms of praxis in practical theology, thus are context-dependent in a strong sense. They are informed by the outcome of empirical and interpretive work. (p. 3)

The acknowledgement that the focus of practical theology is not only directed towards only the theological world, but encompasses all domains of human existence, has direct implications for the understanding of normativity. As a result of these explorations new demands are set not only regarding the interpretation of contexts, but also how normativity should function within non-traditional surroundings, for example social media and more specifically Twitter. In my opinion Osmer (2008:n.p.) presents in his third movement of a practical theological exploration important perspectives to reflect on this challenge. Taking the above explanation seriously leads to the development of a constructive practical theology in which new theological perspectives and patterns are provided for contemporary Christian living in a postmodern digital connected world.

\section{Perspectives for a relevant theological involvement Public theology, practical theology and lived religion}

The development of public theology has precisely the objective to be a prophetic voice from within an orientation where contextual sensitivity plays a big role. Public theology, therefore, dovetails well with practical theology, which emphasises local and concrete practices, which can be described empirically. During the last few years the concept of lived religion has developed strongly in the humanities, in particular in sociology, anthropology, psychology and also practical theology. The concept creates room for the inclusion of the meaning of public and practical theology and places particular significance in tracing the so-called 'sacred 
moments' in common events. ${ }^{8}$ In the consideration of dignity and specifically the Twitter references around the Charlie Hebdo attacks, as well as the South African debate about Steve Hofmeyer and Conrad Koch/Chester Missing, as the practical terrain, lived religion material for further reflection is found.

The challenge to facilitate not only an accountable but also relevant normativity in a contemporary contextual practical theology is, according to Osmer, carried and supported through a 'spirituality of prophetic discernment' (Osmer 2008:n.p.). In this regard Osmer (2008:n.p.) writes: 'The normative task of practical theological interpretation is grounded in the spirituality and practices of discernment'. Important normative markers in the Christian tradition have already been built into this description. 'Prophetic discernment' concerns both divine revelation and the human interpretation thereof for concrete situations. In the description of specific and concrete contexts as well as in the search for signs of the presence of God, empirical research embodies an important moment in the development of practical theology.

In reflecting on the research I am aware that I, as the researcher, implicitly already have a normative position. I implicitly acknowledge that in the formulation of questions regarding theological concepts, grades of correctness can be used. The underlying orientation in this assumption is that I have at my disposal certain normative criteria to enable me to evaluate the correct use of theological concepts. While acknowledging this position I, however, take note of the warning of Henriksen (2006:209) that, 'Normativity is problematic when it precludes us from seeing what we should be able to see as researchers'. The danger could, therefore, be that a one-sided singular understanding of normativity could prevent me as the researcher to consider other perspectives. Precisely for this reason I am sensitive towards considering other possible perspectives regarding normativity. Taking this position I do not want to foster a relativistic position where ' $r$ religion, faith, and theology become only locales of discourse and have no possibility of saying anything about what is true or real' (Root 2014:253). However, in acknowledging my own subjective understanding of normativity, I also open up my horizons of understanding for other possible and alternative perspectives on normativity. The research landscape associated with the project for example implicitly acknowledges that '[ $p$ ]opular culture is both a resource for theologians and a potential source of new theologies' (Willhauck 2013:95).

8.The concepts of praxis and lived religion focus on what people do rather than on 'official' religion, its sacred sources, its institutes, and its doctrines. As such, practical theology has much in common with what in disciplines like anthropology, sociology, and media studies, is known as 'the practical turn': the turn away from institutes and (cultural) texts to the everyday social and cultural practices of ordinary people (Ganzevoort \& Roeland 2014:93).

9.In the orientation of a 'spirituality of discernment' the following is assumed Discernment is the activity of seeking God's guidance amid the circumstances, events, and decisions of life. To discern means to sift through and sort out, much as a prospector must sift out the dross to find nuggets of gold. It also means to weigh a prospector must sift out the dross to find nuggets of gold. It also means to weigh the evidence before reaching a decision, much as a judge
Within this, my own conviction that social media, and in particular Twitter, present an actual and relevant medium for expressions plays an important role. Social media, however, also assume the presence of concrete human beings as unique individuals with personal biographies. In my emphatic involvement with the research I am sensitive that in the search for the use of theological expressions on Twitter, humans as users of Twitter play an essential role. The research, therefore, does not describe normativity quantitatively in the weighing and counting of concepts, but also qualitatively in the acknowledgement of the presence and influence of biographical elements.

\section{Preliminary descriptive perspectives for relevant theological tweeting}

The following, to name just a few, important overarching markers emerged, amongst others, from within the two practice examples that were reflected on.

Social media and more specifically Twitter, as a possible new public sphere, ${ }^{10}$ succeed in presenting new dimensions of normativity and authority. Tweets, which are re-tweeted, give a new dimension to the initial Twitter expression and render a definitive authority to the relative words. It is naturally systematically coupled to the relative profile, which is, ironically, often defined by the so-called 'followers'. Themes addressed on Twitter are very topical and require quick reaction because debates on social media start quickly, but can then disappear as rapidly. Another interesting marker is the use of the 'hashtag' sign, which emphasises certain key aspects of the discussion under question. The expression of key words often has the result that core truths are highlighted for a wide audience and looked at in a new and refreshing manner. Tracing the sacred (Ganzevoort 2009:5) in these contours, one would for example be touching on shades of identity, power, dignity guilt, shame and even humour, to name a few.

\section{Summary and conclusion}

Social media provide for an important platform in the formulation of new accents of normativity. In acknowledgment of this perspective the contribution focused on the role of Twitter in the dynamic formulation of aspects of dignity. Underlying in the presentation of these perspectives are aspects of normativity. By means of presenting a practical theological reflection on selected Twitter data, it was indicated empirically how dignity can be strategically tweeted with the possibility of the creation of a practical theological strategic involvement.

\section{Acknowledgements Competing interests}

The author declares that he has no financial or personal relationships which may have inappropriately influenced him in writing this article.

10.'Twitter revolution claims imply that Twitter constitutes a new public sphere of political communication that has emancipatory potentials' (Fuchs 2014:180). 


\section{References}

Ammerman, N.T., 2014, 'Finding religion in everyday life', Sociology of Religion 75(2), 189-207. https://doi.org/10.1093/socrel/sru013

Astley, J., 2002, Ordinary theology, looking, listening and learning in theology: Explorations in practical, pastoral and empirical theology, Ashgate, Hampshire.

Beaudoin, T., 2014, 'Postmodern practical theology', in K.A. Cahalan \& G.S. Mikosk (eds.), Opening the field of practical theology, an introduction, pp. 187-202, Rowman \& Littlefield, Lanham, MD.

BBC, 2015, 'Charlie Hebdo attack: Three days of terror', 14 January 2015, viewed 27 July 2015, from http://www.bbc.com/news/world-europe-30708237

Browning, D.S., 1991, A fundamental practical theology, descriptive and strategic proposals, Fortress Press, Minneapolis, MN.

Cahalan, K.A. \& Mikoski, G.S., 2014, 'Introduction', in K.A. Cahalan \& G.S. Mikoski (eds.), Opening the field of practical theology, an introduction, pp. 1-10, Rowman \& Littlefield, Lanham.

Cameron, H., Bhatti, D., Duce, C., Sweeney, J. \& Watkins, C., 2010, Talking about God in practice, theological action research and practical theology, SCM Press, London.

eNCA, 2014a, Chester missing as Steve and Conrad enter the ring, viewed 04 Augus 2015, from http://www.enca.com/south-africa/round-two-chester-and-steveback-ring.

eNCA, 2014b, Court cancels Steve Hofmeyr protection order against Chester Missing, World Wide Web, viewed 4 August 2015, from http://www.enca.com/southafrica/court-cancels-steve-hofmeyr-protection-order-against-chester-missing.

Fuchs, C., 2014, Social Media - A critical introduction, Sage, London.

Fuseware, 2015, Your complete media monitoring solution, viewed 17 April 2015, from http://www.fuseware.net

Ganzevoort, R.R., 2009, Forks in the road when tracing the sacred: Practical theology as hermeneutics of lived religion, viewed 24 April 2010, from http://www. ruardganzevoort.nl/pdf/2009_Presidential.pdf

Ganzevoort, R.R., 2014, 'Hoe leiden we anno 2014 goede theologen op?', Handelingen 41(3), 20-30, viewed 7 September 2015, from http://www.ruardganzevoort.nl/ pdf/2014_Opleiden_Theologen.pdf

Ganzevoort, R.R. \& Roeland, J., 2014, 'Lived religion: The praxis of practical theology', International Journal of Practical Theology 18(1), 91-101. https://doi. org/10.1515/ijpt-2014-0007

Henriksen, J.O., 2006, 'Researching theological normativity, some critical and constructive suggestions', Studia Theologica 60, 207-220. https://doi. org $/ 10.1080 / 00393380601010185$

Hermans, C.A.M., 2014, 'From practical theology to practice-oriented theology', International Journal of Practical Theology 18(1), 113-126. https://doi org/10.1515/ijpt-2014-0009

Hofmeyr, S., 2015, 'Steve Hofmeyr', viewed 18 July 2015, from http://stevehofmeyr. co.za.

Holmberg, K., Bastubacka, J. \& Thelwall, M., 2016, ‘@God please open your fridge! A content analysis of Twitter messages to @God: Hopes, humor, spirituality, and profanities', Journal of Religion, Media and Digital Culture 2(5), 339-335.
Kaufman, T.S., 2016, 'From the outside, within, or in between? Normativity at work in empirical practical theological research', in J.A. Mecer \& B.J. Miller-McLemore (eds.), Conundrums in practical theology, pp. 134-162, Brill, Boston, MA.

Koch, C., 2015, 'Conradkochblogspot', viewed 2 August 2015, from http://conradkoch. blogspot.com.

Lutz, B. \& Du Toit, P., 2015, Defining democracy in a digital age: Political support on social media, Palgrave MacMillan (Kindle Edition), London.

News24, 2014, 'Chester missing to Hofmeyr: I'm gonna burn u', 6 November 2014 viewed 10 July 2014, from http://www.news24.com/Archives/City-Press/ChesterMissing-to-Hofmeyr-I-am-gonna-burn-u-20150429

Osmer, R.R., 2008, Practical theology: An introduction, Wm B. Eerdmans (Kindle Edition), Grand Rapids, MI.

Osmer, R.R., 2012, 'Practical theology', in K.M. Kapic \& B.L. McCormack (eds.), Mapping modern theology, a thematic and historical introduction, pp. 319-344, Baker Academic, Grand Rapids, MI

Osmer, R.R., 2014, 'Empirical practical theology', in K.A. Cahalan \& G.S. Mikoski (eds.), Opening the field of practical theology, an introduction, pp. 61-77, Rowman \& Littlefield, Lanham, MD.

Osmer, R.R. \& Schweitzer, F.L., 2003, 'Introduction', in R.R. Osmer \& F.L. Schweitzer (eds.), Developing a public faith, new directions in practical theology, pp. 1-11, Chalice Press, St. Louis, MO

Root, A., 2014, Christopraxis, a practical theology of the cross, Fortress Press, Minneapolis, MN.

Stoehr, A., 2016, 'Normativity as a social resource in social media practices', in M.M. Lian, M.S. Karrebaek \& J.S. Møller (eds.), Everyday language, collaborative research on the language use of children and youth, n.p., Trends in Applied Linguistics, Mouton De Gruyter, Berlin.

Vorster, N., 2012, 'A theological perspective on human dignity, equality and freedom', Verbum et Ecclesia 33(1), Art. \#719, 1-6. https://doi.org/10.4102/ve.v33i1.719

Wigg-Stevenson, N., 2015, 'From proclamation to conversation: Ethnographic disruptions to theological normativity', Palgrave Communications 1, 150241. https://doi.org/10.1057/palcomms.2015.24

Willhauck, S., 2013, 'The urban dictionary, street wisdom and God: An intersection of linguistics and theology', International Journal of Practical Theology 17(1), 88-99. https://doi.org/10.1515/ijpt-2013-0007

@chrchristensen, 2015, 'Prof. of Journalism at Stockholm University. American. Also lived in UK \& Turkey. @Guardian \& @CommonDreams contributor. Tweets own opinion, not my employer's', viewed 23 September 2015, from https://twitter. com/ChrChristensen/status/552903106556870657

@glengilmore, 2015, 'FORBES top 20 social media http://bit.ly/10405Mx TIME Man of Action http://goo.gl/KISPW Speaker \#DigitalMarketing Author \#DigitalTransformation | \#Al \#AR \#loT Rutgers Adj', viewed 24 September 2015 from https://twitter.com/GlenGilmore/status/553555389611274240

@islam4christians, 2015, 'This account intends to be a main informative online source of knowledge about the true message of Prophet Jesus and how Muslims view him', viewed 24 September 2015, from https://twitter.com/islam4christian/ status/55313951517155737 